\title{
Failure and damage determination of building roofs
}

\section{Análisis de los fallos y daños en las cubiertas de los edificios}

Manuel J. Carretero-Ayuso (Main Author)

Departamento de Expresión Gráfica, Escuela Politécnica, Universidad de Extremadura. Fundación Musaat carreteroayuso@yahoo.es

\section{Alberto Moreno-Cansado}

Departamento de Ingeniería Mecánica, Energética y Materiales, Centro Universitario de Mérida Universidad de Extremadura. Fundación Musaat

albertmoreno57@hotmail.com

Jorge de Brito (Corresponding author)

Departamento de Engenharia Civil, Arquitetura e Georrecursos, Universidade de Lisboa. CERIS-ICIST.

Av. Rovisco Pais, 1049-001, Lisboa, Portugal. Phone +351 218419709

jb@civil.ist.utl.pt

Manuscript Code: 764

Date of Acceptance/Reception: 14.03.2017/20.04.2016

DOI: $10.7764 /$ RDLC.16.1.145

\begin{abstract}
This paper presents the analysis of 801 damage occurrences in building roofs, which were classified qualitatively as well as quantitatively. They have been correlated according to the type of roof in question, and the most frequent situations have been determined. The prevalence of the causes behind these problems is indicated, and a technical discussion concerning each one is presented. These results provide property developers, designers and construction managers with information on the critical points of roofs, as a way to minimize defects in their building sites. This damage analysis provides a series of lessons learnt in order to improve the quality of construction in general.
\end{abstract}

Key words: Roofs, research, anomalies, recurring, damage, Spain.

\section{Resumen}

Esta investigación presenta el análisis de 801 daños relativos a las cubiertas de edificios, los cuales han sido clasificados cualitativa y cuantitativamente. Se han correlacionado los mismos según el tipo de cubierta donde se daban, así como determinado cuáles eran las situaciones más recurrentes. Se informan e indican de los valores porcentuales de las causas que han provocado dichos daños, incluyendo una discusión técnica para cada una de ellas. Con todos estos resultados se ofrece a los promotores, proyectistas y responsables de obras cuáles son los puntos críticos de las cubiertas como forma de minimizar los defectos en sus obras. El análisis de estos fallos nos proporcionará una serie de lecciones aprendidas para mejorar la calidad de la construcción en general.

Palabras clave: Cubiertas, investigación, patologías, recurrentes, daños, España.

Introduction

The analysis of mistakes in engineering allows technicians to quickly and effectively learn from instances in which some stage of the process (design, development, materials...) unfolded differently from expected. This leads to situations as diverse as research into the effects of storms in roof-wall connections (Guha \& Kopp, 2014) or the determination of wear by corrosion-erosion of fire (Guzmán, Martínez \& González, 2014).

Among the anomalies or deficiencies which roofs are subject to, not all become pathological, while some can be catastrophic (Piskoty et al., 2013). The level of their impact may not imply a critical situation; meanwhile, many anomalies can lead to the same type of damage.

The reduction of deficiencies (whether they be deficiencies arising from the design or execution stages) would allow buildings' service life to be longer and of higher quality. Thus, the regular control interventions in buildings acquire ever greater importance due to the costs of processes as well as their social relevance. This fact, along with an adequate management of building maintenance, will allow optimizing resources, attaining sustainable development and reducing expenses caused by lack of quality (Raposo, Fonseca \& Brito, 2011).

Inexplicably, roofs are usually not inspected regularly, despite the simplicity of carrying out a simple visual inspection. Therefore, small anomalies that are not expected to cause immediate problems turn into water infiltrations due to the 
lack of corrective actions (Garcez, Lopes, Brito \& Silvestre, 2012). Flat roofs' predisposition for problems has been recognised even by some old construction treatises. In a book written by an 18th century architect it is stated that, if roofs are not built correctly, they will require frequent repairs (Bails, 1796).

As several authors state (Vaz Paulo, Branco \& Brito, 2011), the evaluation and classification of defects in architectural and engineering infrastructures is a common practice during construction inspections (Flores-Colen, de Brito \& de Freitas, 2008). Concerning this aspect, this last study refers an example of the consequences that can emerge when quality control (whether design or execution controls) is not carried out, or is carried out inefficiently.

Mesa Fernandez, Palacios González, Álvarez Cabal \& Villanueva Balsera (2016) determined the quality defects of a sample of housing buildings. This work was focused on the analysis of the initial stage if planning of the quality control. Even though greater repercussions on the companies of that sector, the authors identified and studied a series of defects of various gravity and nature.

The literature reviewed in relation to flat roofs commonly focus on the study of materials - such as in the case of some experimental research that has been carried out to better know the influence of the various components of waterproofing systems. One such research studied the performance and placement of fastening systems in membranes on deck roofs (Ko, Molleti, Bishop \& Baskaran, 2006). Other authors (Silva, Lopes \& Correia, 2010) carried out a campaign of tests aiming to evaluate the influence of the thickness of insulating materials and the manufacturing of APP polymermodified bitumen membranes. Their conclusions were that the thickness of the insulating materials appears not to affect the resistance of membranes' mechanical fastening systems, as is the case for the types, weight of the reinforcement or mass of the waterproofing membranes themselves. Further, members of a team of the Institute for Research in Construction (Ottawa-Ontario-Canada) researched the behaviour of fastening systems of bituminous membranes exposed to wind in both dynamic and static modes, reaching admissible load values (Chen, Baskaran \& Lei, 1998).

Other researches consider different aspects, highlighting the importance of the design stage, for its primordial importance on the durability of construction elements in general and, as a result, on buildings' service life (Garcez, Lopes, de Brito, Sá \& Silvestre, 2015). On the other hand, an environmental analysis of the life cycle, based on an evaluation of different replacement options, may affect the choice of the sustainable design alternatives of flat roofs (Napolano, Menna, Asprone, Prota \& Manfredi, 2015).

According to Azorín López \& Monjo Carrió (2005), the analysis of the anomalies indicated above can be of great interest in construction. The sector is one of the Spanish production areas generating more complaints from the users. This fact outlines a clear dissatisfaction of the users, but also shows that some technical aspects should be improved to improve the quality of the building stock. A number of documents have been considered and drafted in Spain for technicians to learn how to execute the more critical points of flat roofs, based on prior knowledge of these common anomalies.

The statistical progression of these complaints, and the analysis of the damage leading to them, can help survey the construction sector and identify the deficiencies that are most prevalent in a given country (Sarman, Nawi, Che-Ani \& Mazlan, 2015).

Aiming to obtain and consult a similar reference, the available literature was reviewed, but no analogous models were found. There is previous research (Walter, Brito \& Lopes, 2005) in which these anomalies were classified, but focusing on waterproofing of bituminous membranes in flat roofs based on a chronological criterion: design, application, accidental external mechanical action and environmental actions. While the paper in question is doubtless very interesting, it could not be used as a basis since the sources reviewed here are reports that were already prepared. In addition, the object of these reports was not to formally classify any anomalies, but rather to note pathological damage based on the complaints of the buildings' owners.

The objective of this work is to perform a quantitative and qualitative analysis of the presence of anomalies in building roofs recently built in Spain, as well as to establish their frequency. The results presented allow real estate promoters and designers to minimize the number of anomalies in roofs and contractors to acquire the know-how to reduce errors during the construction.

Methodology

This research relies on data from records of the civil responsibility insurance of Spanish quantity-surveyors and technical architects (MUSAAT, 2008-2010) that have an associated legal complaint filed in the years 2008, 2009 and 2010 and a court ruling prior to June 2011 (SERJUTECA, 2008-2010). 
A total of 1166 records were considered, and it was necessary to systemize the transcription of data via a specially designed sheet. A total of 801 anomalies related to roofs were extracted from the records, following their review.

This paper reviews the data sources of the work titled "National Statistical Analysis on Construction Anomalies" of the 'MUSAAT Foundation' - Spain - (Carretero-Ayuso \& Moreno-Cansado, 2013). This document intends to provide the specific data relating to the roofs of the buildings studied, incorporating an analysis of the results and a discussion on this matter.

The study focused on a general concept of interrelationship to characterize and locate each of the pathological processes studied within a "quadrinomial". Each of those four descriptors (key concepts on which the research was based) provides the essential features identifying the "Zone-Element-Damage-Cause" process. As mentioned, the detailed reading of every record (each with hundreds of pages) was necessary to extract therefrom the technical and pathological data of the cases, with the aim of characterizing them qualitatively and quantitatively. In this perspective, this paper intends to present the data collection, classification, analysis and results found in roofs studied.

\section{Classification of the construction elements}

Roofs are typically of two classical types (Table 1).

Table 1. Classification of the construction elements. Source: self-elaboration.

\begin{tabular}{ccc}
\hline COD.-e & Construction element & Number studied \\
\hline e17 & Flat (roofs) & 550 \\
e18 & Pitched (roofs) & 251 \\
\hline
\end{tabular}

According to the Construction Technical Code, which is the Spanish regulation for the design and execution of these construction elements, the conceptual distinction that is made between them concerns the slope (Ministerio de la Vivienda, 2006). It is considered that pitched roofs are those whose slope is greater than $5 \%$ (with various materials being used: slates, tiles, metallic plates...) and that flat roofs are those with a slope $\leq 5 \%$ (even though greater than or equal to $1 \%)$.

\section{Classification of the types of damage}

The 801 instances of damage studied were classified and grouped into seven types of damage. Table 2 lists and links those types of damage to the data obtained from the statistical results of the research carried out. Figure 1 includes a number of photographs that illustrate each of the types of damage indicated in Table 2, colour-coded by set of similar anomalies. The Spanish regulation UNE-41805-9-IN (AENOR, 2009b), which focuses on the 'diagnosis of anomalies on building roofs', classifies the processes of deterioration of this area in five groups:

1) Humidity;

2) Cracks;

3) Detachments and fall of elements;

4) Loss of surface material and deterioration of the elements;

5) Activity by organisms and growth of vegetation.

\begin{tabular}{ll} 
& Table 2. List of the types of damage. Source: self-elaboration. \\
\hline COD.-D & Classification of the types of damage \\
\hline D01 & Infiltration humidity \\
D04 & Localized infiltrations \\
D06 & Condensation humidity \\
D11 & Others/no data (1) \\
D21 & Cracks in parapets \\
D26 & Cracks in gable-walls and platbands \\
D46 & Detached copings \\
\hline
\end{tabular}

(1) Others/no data: the type of damage is unlike any of those established in this study or there are no data to define specific damage. 
This categorization helps to visualize in which of them the seven types of damage resulting from this research can be inserted. In this regard, D01, D04 and D06 clearly fall under the ' $a$ ' category (humidity); D21 and D26 under the 'b' category (cracks and fissures) and D46 under the ' $c$ ' category (detachment and falls). Given that the studied buildings were new and not much time had passed since the preparation of the anomaly reports, it is understandable that no anomalies emerged that could be included in categories ' $d$ ' and ' $e$ '.

Figure 1. Graphical examples of the types of damage groups by similar anomalies. Source: images by Manuel J. Carretero-Ayuso.

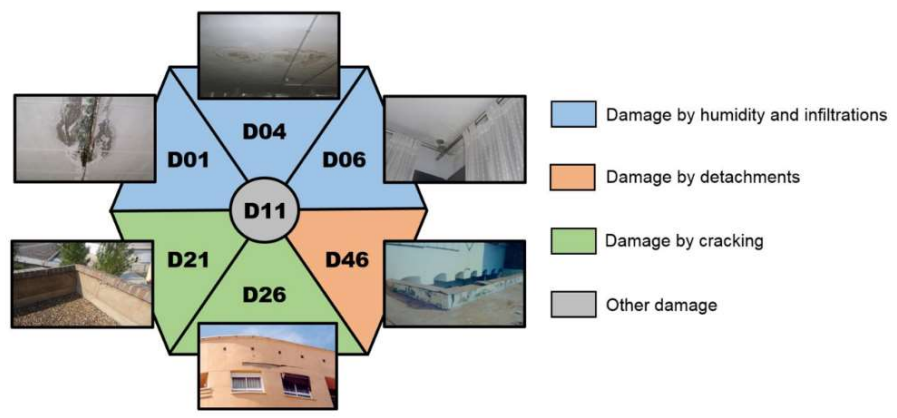

With the goal of comparing the damage of Table 2 with that described in other references, a research paper on 23 buildings in Malaysia was carefully reviewed (Sarman et al., 2015). In it, defects are assembled into three big groups: 'defects related to superficial aspects', 'waterproofing defects' and 'cracks'. The first includes the presence of mould, dust, dirt and vegetation. These situations were not found in this Spanish study, plausibly due to the fact that, unlike the Malaysian research that contemplated buildings up to 37 years old, it only analyzed young buildings.

Nevertheless, - even though the current construction techniques are not the same -, similarities were found in the second group (waterproofing defects), as the D1, D4 and D6 anomalies are found in it, and in related areas: tail-ends with parapets, connections with downspouts and unions between layers or membranes. On the other hand, in the third group (cracks), reference is made to the same critical points indicated herein (basically, D21 and D26), for which reason it can be indicated that the Malaysian study and this Spanish one have found analogous and compatible defects and damages, while named and expressed distinctly.

\section{Classification of the causes}

The causes of the damages were classified according to 13 types of causes (Table 3) with regard to the roofs under analysis.

Table 3. List of the types of causes. Source: self-elaboration.

\begin{tabular}{ll}
\hline COD.-C & Name of the cause \\
\hline 02C & Absence/deficiency of sealing \\
06C & Absence of/poor construction joints \\
07C & Absence of/inadequate thermal isolation \\
08C & Absence/inadequate positioning of waterproofing membranes \\
$11 C$ & Unknown reason/no diagnosis (1) \\
$15 C$ & Expansion movements \\
$19 C$ & Poor detailing of tail-ends in drains and grids \\
$21 C$ & Inadequate slope of cladding element \\
$22 C$ & Absence/inadequate positioning of roof tiles \\
$24 C$ & Absence/deficient execution of singularities \\
$26 C$ & Deficient tail-ends with vertical surfaces (Figure 2) \\
$44 C$ & Punching of the waterproofing membrane \\
$69 C$ & Absence of/inadequate ventilation of the attic space under the roof \\
\hline
\end{tabular}

(1) Unknown reason/no diagnosis: the reason is not among those established in this research or there is no data to define a specific reason. 


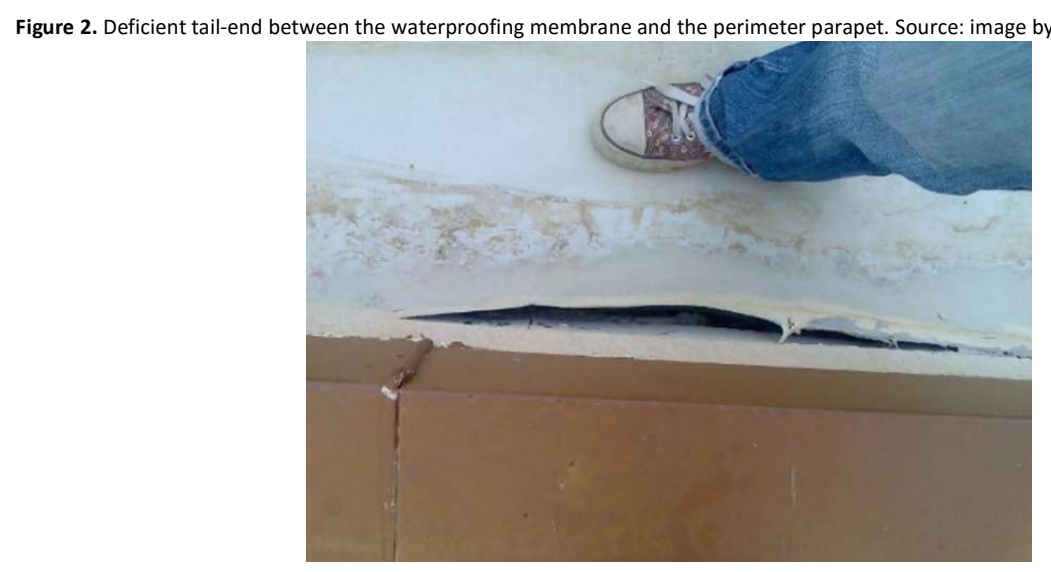

Of the 57 possible types of conceptual causes proposed in one of the above-mentioned papers (Walter et al., 2005), it is difficult to find a correspondence as it includes only flat roofs. Nevertheless, Table 4 attempts to establish a relationship, as no real and indistinct biunivocal correspondence exists.

\begin{tabular}{lcc}
\multicolumn{2}{l}{ Table 4. Relationship between the causes of Walter et al. (2005) and Garcez et al. (2012) and those of this research. Source: self-elaboration. } \\
\hline & $\begin{array}{c}\text { Causes in the research by } \\
\text { Garcez et al. (2012) }\end{array}$ & $\begin{array}{c}\text { Causes in the research by Walter et al. } \\
\text { Cause in this research }\end{array}$ \\
\hline $02 C \rightarrow$ & C-E11 & C-B11/C-B12 \\
$06 C \rightarrow$ & C-P1 & C-A1/C-A2/C-A3 \\
$07 C \rightarrow$ & C-P4 / C-E4 & C-A13/C-B9 \\
$08 C \rightarrow$ & Not applicable & C-B8/C-B9/C-B10/C-B11/C-B12 \\
$11 C \rightarrow$ & -- & -- \\
$15 C \rightarrow$ & C-M1 (partially) & C-A3/C-A8/ C-B13 \\
$19 C \rightarrow$ & Not applicable & C-A5/C-A10/C-A14/ C-A15/C-B5/C-B14 \\
$21 C \rightarrow$ & C-P2 & C-A19 \\
$22 C \rightarrow$ & C-P7 / C-E10 & Not applicable \\
$24 C \rightarrow$ & C-P6 / C-P8 / C-E3 / C-E5 & C-A18/C-B8 \\
$26 C \rightarrow$ & No correspondence & C-A1/C-A4/ C-A17/C-A6/C-B8 \\
$44 C \rightarrow$ & Not applicable & C-B7/C-B6/C-C1/C-C2/C-C3/C-C4/C-C6 \\
$69 C \rightarrow$ & C-P3 / C-E3 & Not applicable \\
\hline
\end{tabular}

Table 5. Comparison between the causes of Sarman et al. (2015) and this research Source: self-elaboration.

\begin{tabular}{ll}
\hline Causes in the research by Sarman et al. (2015) & Causes in this research \\
\hline Roof slope percentage & $\rightarrow$ Analogous to 21C \\
Rugged and unequal surfaces & $\rightarrow$ Analogous to 44C \\
Problems with water drainage & $\rightarrow$ Analogous to 19C \\
Cracks in tail-ends with parapets & $\rightarrow$ Analogous to 06C / 26C \\
Unions between layers or membranes & $\rightarrow$ Analogous to 08C \\
Thermal expansion of the perimeter walls & $\rightarrow$ Analogous to 07C / 15C \\
Construction not according to specification & $\rightarrow$ Analogous to 24C \\
\hline
\end{tabular}

General concepts dealt with by Walter et al. (2005), such as 'inexistent or deficient supervision or quality control (CB16)', could be related to a large extent with the causes behind multiple types of damage outlined in this research. Let us now consider another bibliographic reference consulted concerning 'pathology, diagnosis and repair of ceramic tile pitched roofs' (Garcez, Lopes, de Brito \& Sá, 2012). The fundamental difference observed is that this previous study focuses on a sample of relatively old buildings, which display a number of anomalies (deficient subsequent interventions, misalignments, vegetation growth...) that are not translatable to the present study given that in this case the buildings are quite recent. Nevertheless, Table 4 attempts a correspondence between the caused diagnosed herein and 
those presented in Garcez et al. (2012). If the comparison of the causes is now made with the Malaysian study of (Sarman et al., 2015), a number of pairs can be established in function of the causes in this research, specifically concerning flat roofs (Table 5).

Results

The results obtained are presented next, in terms of the type of roof (pitched or flat), the anomalies found according to each of the typified damage, the causes behind the pathological processes, as well as a comparison with the results from the stages previous to the construction.

\section{Percentage of damage per construction element}

Of the 801 anomalies studied, 550 correspond to flat roofs (68.66\%) and 251 to pitched roofs (31.34\%). This means that practically 7 out of 10 cases relate to flat roofs (bearing in mind that the number of elements studied - cases reaching trial - is equal to the total number of instances of damage).

Water tightness is far more critical in flat roofs because of their small slope, for which reason it must be ensured that water does not enter the building, via a proper placing of a waterproofing membrane. This entails a number of obstacles, given the particularities with which the tail-ends in singularities must be executed (anchorages, free edges, chimneys, etc.). Furthermore, the different types of flat roofs (with or without insulation, with insulation above or below the waterproofing membrane, existence of separating layers, different types of finishing depending on whether they are accessible roofs, etc.) add complexity and variety to the construction process. All of this, in addition to a need for greater specialization of the workers, explains this greater prevalence of anomalies.

\section{Types of damage according to their frequency}

The anomalies studied have been assembled into seven groups (types of damage). Figure 3 details these, sorted by their damage code and differentiating the damage pertaining to flat roofs, pitched roofs, as well as their grand total. As can be noted, the damage relating to water infiltrations (D01 and D04) comprise over 3/4 of the total. This underlines the low quality of construction, and that those deficiencies are so critical that they lead to the direct entry of water into the rooms underneath the roofs.

Decidedly, this information is of great interest to the technicians responsible for the construction, but also those involved in the organization of the construction companies. In both cases (each within their own sphere of responsibility), they should take the necessary measures to ensure that these damages do not occur, by increasing controls and inspections. The most significant problems are those related to the presence of water, as they are easily noticeable by the users. This important presence of damages D01 and D04 makes it impossible to ensure adequate durability in the shortterm. Some authors (Harrison, Trotman \& Saunders, 1996) state that durability should be one of the most relevant properties in obtaining an adequate maintenance and ensuring that the building's basic functions are preserved over time.

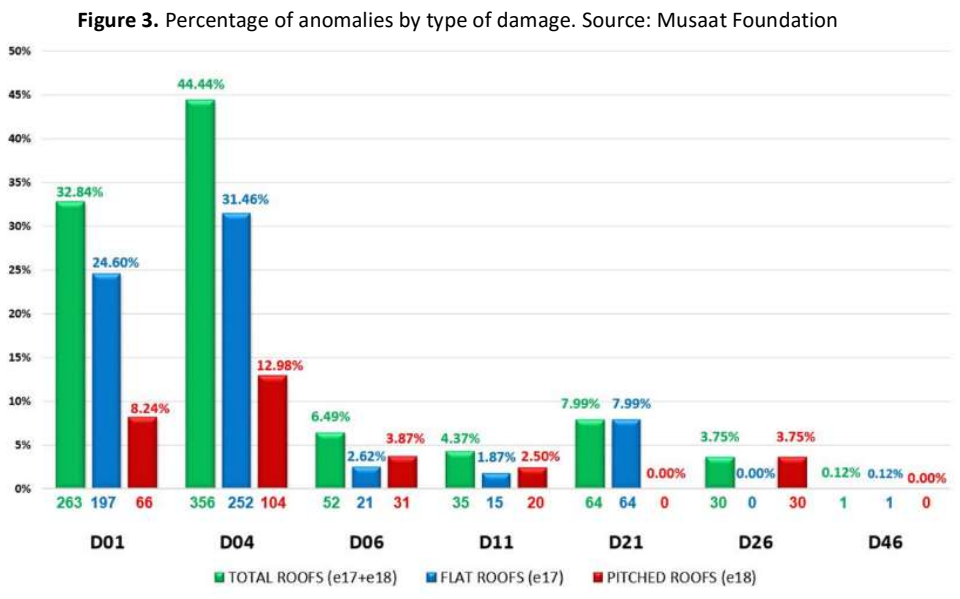


This factor, users' actions, explains the difference from the results of another research (Garcez et al., 2012) given that only those anomalies that are converted into an actual problem (damage), and are perceived by the users as such result in court cases. In that research (considering 62 ceramic tile pitched roofs on buildings of varying ages), the most prevalent anomalies were A-06 (Defects in the ventilation system - 88.7\%), A-02 (Defects in the tail-ends - 88.7\%), A-E4 (Growth of vegetation/biological colonization - 87.1\%) and A-O5 (Defects in the thermal insulation - 71.0\%).

Among the main anomalies detected in the flat roofs of the research by (Walter et al., 2005) are A-A3 (Detachment of the overlap joints), A-A7 (Cracks), A-C1 (Fracture of joints) and A-D1 (Perforations and tears). All of these lead mainly to the most frequent damage determined herein (D01 and D04), and are therefore directly correlated with them.

\section{Types of causes according to their prevalence}

Figure 4 relates the 13 types according to which the causes of damage have been classified. It stands out that the seven most frequent causes account for $82.40 \%$ of instances ( 660 of the cases studied). These cases are those anomalies which occurred at least 50 times.

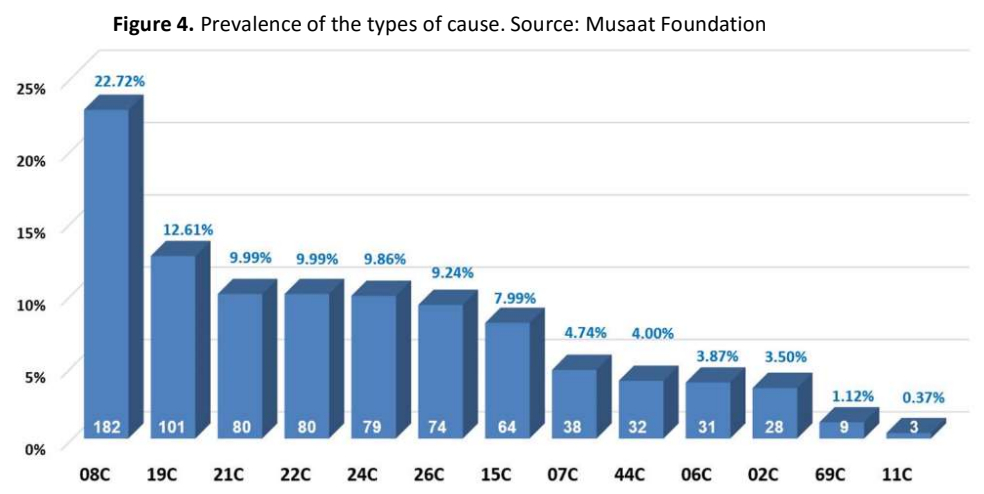

Causes $08 \mathrm{C}$ and $19 \mathrm{C}$ are behind many anomalies of flat roofs, which account for $37 \%$ more damages than pitched roofs. This is both significant and cause for concern given that building waterproofing in Spain is more and more sub-contracted to official installation firms, and yet there are no positive results. In this regard, the 'deficient tail-end with drains and grids' (cause 19C) does not seem to decrease with specialized labour, which would be highly desirable given that the drainage of rainwater is fundamental for flat roofs.

Causes $21 \mathrm{C}$ and $22 \mathrm{C}$ can be interpreted as requiring an improvement in protection/cladding elements, whereas causes $24 \mathrm{C}$ and $26 \mathrm{C}$ denote a group of problems resulting from a lack of care in the tail-ends between the roof plans and other roof elements.

The specific results of Figure 4 cannot be compared to those of the study by Garcez et al. (2012) since that one does not have unit values, but instead the conceptual determination of whether the causes are generally motivated in the design stage, in the execution stage, in the maintenance stage, etc. In another key study (Walter et al., 2005), the causes are not detailed with increasing linear values, for which reason it is necessary to resort to an existing correlation matrix, to know the results in function of each parameter in particular.

\section{Comparison with the results of previous stages of the building process}

It is interesting to see which relation might exist between the most frequent execution deficiencies found in roofs and the anomalies and damages studied in this research. According to a recent study evaluating this aspect in flat roofs (Carretero-Ayuso \& Brito, 2016a), the most frequent deficiencies are: 'height of the membrane's vertical tail-end lower than in the standard (P8)' and 'height of the sill lower than in the standard (P9)' and 'no primer applied on the adhesion area (P5)'; all situated in the 'tail-end with the parapets' location group. All can lead to either of the two anomalies most frequent here: 'infiltration humidity (D01)' or 'localized infiltrations (D04)'. In turn, in the other location where problems are most frequent - 'tail-end with drain nozzles' - the most frequent deficiencies were 'no primer applied before applying the drain nozzle's reinforcement membrane (D4)' and 'drain nozzle incompatible with the waterproofing membrane (D3)'; both also produce the damage indicated. 
Similarly, there is another study which evaluates the execution deficiencies in pitched roofs (Carretero-Ayuso \& Brito, 2016b), which concludes that the most frequent are: 'Missing/insufficiently or incorrectly placed ventilation roof tiles $(F 2)^{\prime}$, 'the coping stone has insufficient lateral slope and/or has no drip (S4)', 'the lateral connection between the roof plans and the gables is deficient (P2)' and 'deficient/poorly executed tail-end of roof plans with plumbing and chimneys (S1)'. The first can lead to damage D06, the second to D01, the third to D04 and D26 and the fourth to D01 and D04.

Discussion

The next two sections intend to facilitate the inspection and survey of building sites, based on the results obtained: an explanation of the causes of each anomaly and recommendations on how to waterproof the three main singularities of flat roofs.

\section{Comments on the causes found}

The technical documents used during the construction process should be carefully drafted. They could summarize the regulations and the recommendations of experts in a complete and detailed manner, serving as a basis for consultation between the interveners (Solar Serrano, 2014). Figure 5 contains a series of reflections and explanations on each of the causes typified in this study, while incorporating photographs that help better understand them.

Figure 5. Technical discussion of the types of causes. Source: images by Manuel J. Carretero-Ayuso.

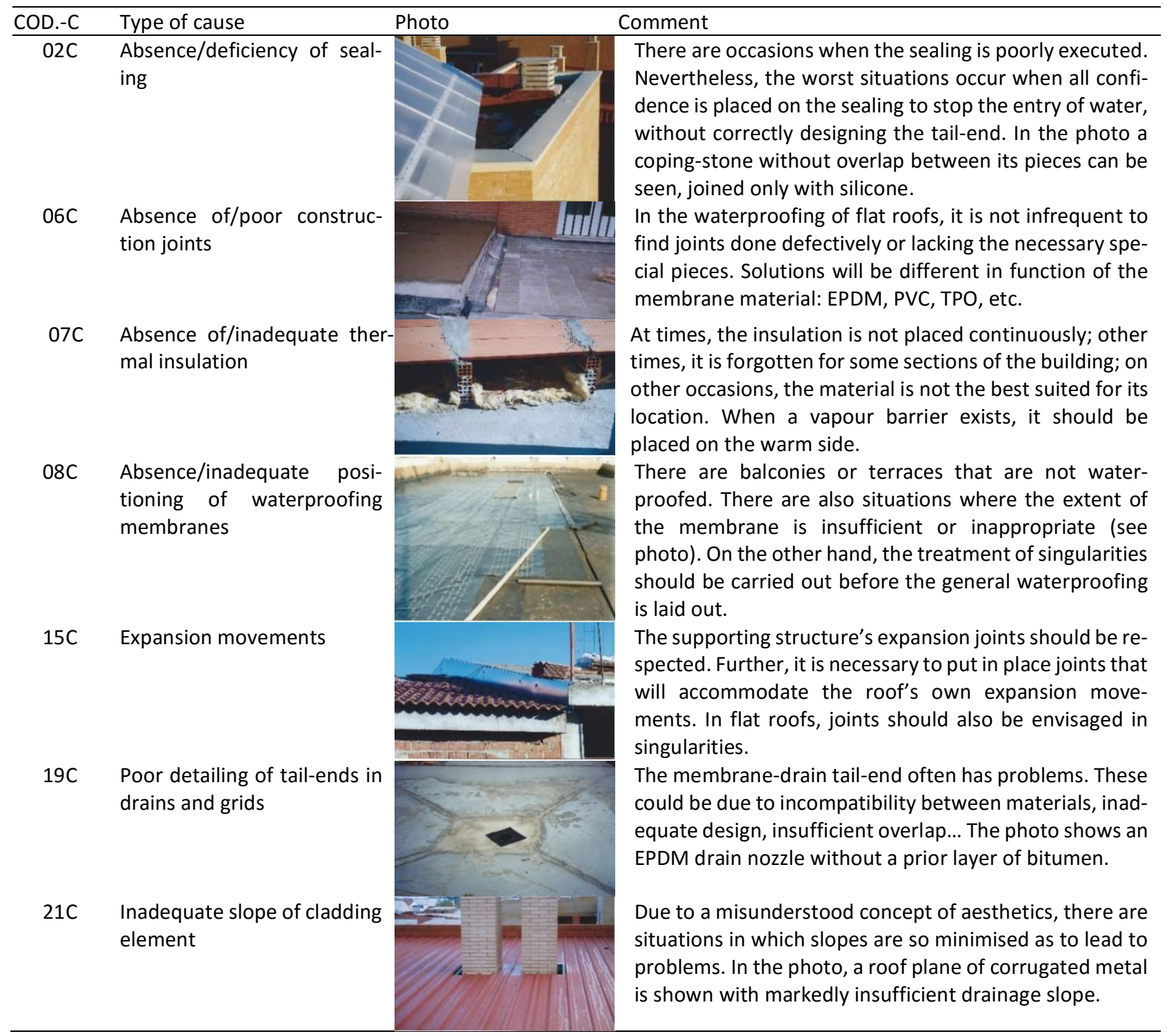


22C Absence/inadequate positioning of roof tiles

$24 C$

Absence/deficient execution of singularities

$26 C$

Deficient tail-ends with vertical surfaces

$44 C$

Punching of the waterproofing membrane

$69 C$

Absence of/inadequate ventilation of the attic space under the roof
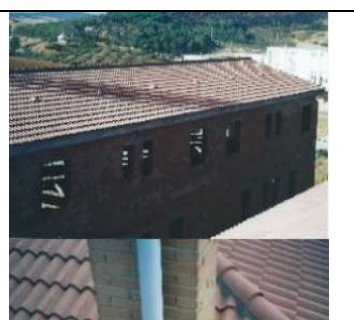

Roofs' protective elements should possess a minimum slope to allow for drainage, as well as the overlap or placing that will allow them to function properly. In the case of tiles, their fastening and tail-ends with roof edges should also be carried out with care.

Singularities are not always well defined and located in design documentation (chimney, downspouts, ventilation elements, masts, anchorages...). In the photo a situation where a number of these elements are concentrated next to a roof hip and a ridge cap can be seen.

The tail-ends between the roofs and the attached walls should be carried out with the greatest care in order to ensure that there are no infiltrations in these areas. There should be some clearance and, to ensure this, specific pieces and constructive configurations should be used.

Waterproofing membranes can be perforated on the upper side if piercing elements are placed on them. Perforation can also occur on the lower side when, for example, the supporting elements are irregular or have perforating debris.

It is necessary to ventilate roofs, and to do so with sufficient amount of air flow. For that purpose special pieces should be used (such as ventilation tiles), or openings should be made in the parapets, or ridge caps underneath the perimeter walls, allowing for proper circulation.

\section{Recommendations for the construction of singularities}

Below are presented a series of recommendations/remarks for the execution of the main singularities of flat roofs (those with the most problems) which, it is hoped, will be useful for engineering students and technicians (Figure 6). They can be regarded as a methodology to be followed in order to minimize errors (centred on roofs executed with bituminous membranes, which are the most common in Spain and in much of Europe).

While specific regulation exists for the placement of waterproofing systems (AENOR, 1996) (AENOR, 1999) (AENOR, 2009a), this is usually disregarded in the design and execution of construction projects, likely due to its complexity. It is hoped that the table below, designed as it is to be easily consulted by the relevant persons, will address this problem. 
Figure 6. Remarks and infographics concerning the most important singularities in flat roofs. Source: images by Manuel J. Carretero-Ayuso.
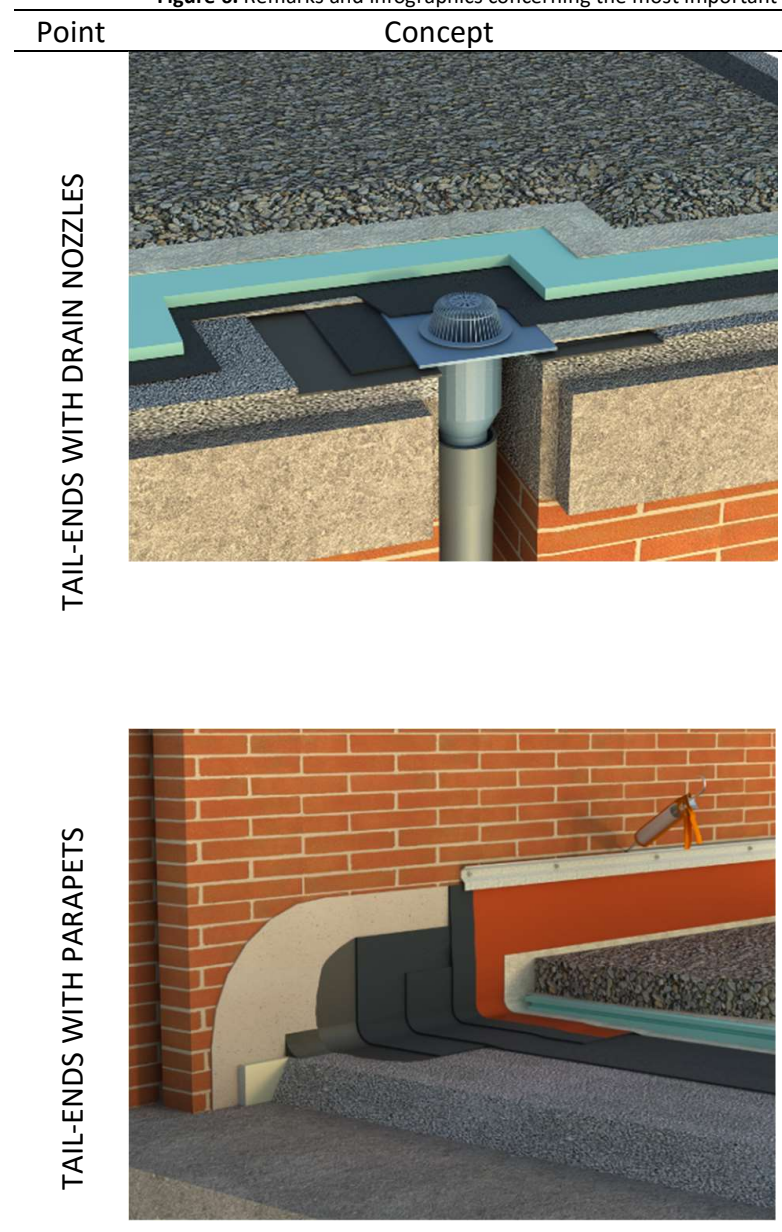

- The drain nozzle should be pre-fabricated and designed for this purpose. It should have a sufficient upper perimeter flap and adequate depth to allow for proper drainage of water. It should be of a material that is compatible with the waterproofing layer.

- The surface of the mouth of the drain nozzle should be about $50 \%$ greater than the section of the downspout it is connected to.

- The placement process should be as follows:

-Bituminous priming where the reinforcement shall be;

- Placement of a reinforcement membrane with a blowtorch on its downsize;

-Placement of drain nozzle by welding it to the reinforcement membrane by means of a flame, until total adhesion;

- Placement of the general membrane, having it adhered in its down surface by means of heat to the drain nozzle and to the reinforcement membrane.

- Application of bituminous primer to the lower part of the parapet and to the upper part of the roof plan;

- Placement, at an angle, of a reinforcement-adhesion membrane ( $50 \mathrm{~cm}$ wide) glued to the supporting element in all its extension, by heating;

- Application and execution of the general membrane (already formed by one or by two bituminous membranes);

- Placement, on the upper surface, of the flush parapet membrane (40 cm strip);

- Placement of a stainless metallic profile in the membrane's tail-end area (fastening at every $25 \mathrm{~cm}$ ) and sealed above it with polyurethane mastic or similar;

- In place of this profile, there can also be a reinforcement of the entire tail-end, or the insertion of a clearance of $3 \times 3 \mathrm{~cm}$.

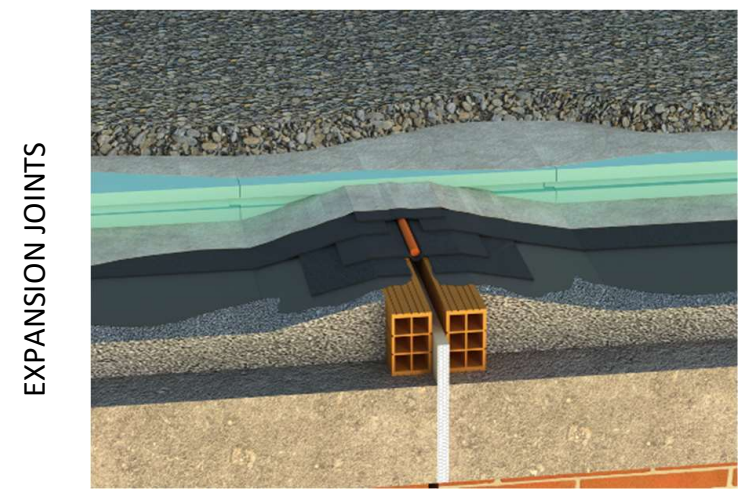

- Application over the supporting surface of a bituminous primer and placement of two adhesion strips $30 \mathrm{~cm}$ side, adhered by means of heat;

- Placement of a reinforcement membrane, shaped as a ' $U$ ' or loop, of the same waterproofing material, $40 \mathrm{~cm}$ wide and adhering to each lateral adhesion strip;

- Placement, on both sides, of the general waterproofing up to the edge of the joint;

- Placement of a cylindrical compressible filling cord compatible with the membrane;

- Insertion of an edge strip (45 cm wide strip, also shaped as a ' $U$ ' or loop), centred on the joint and adhering at each edge to the general waterproofing.

The choice to display these construction details in 3D is based on the idea that this type of visualization allows a more intuitive learning of new concepts and a greater ease in retaining knowledge. In some experienced, the Sketchup program was used to evaluate notions of geometry in the subject of mathematics and to relate transversal views of 2D sections with 3D objects (Kurtulus \& Uygan, 2010). Other studies attempted to evaluate understanding by means of drawing tools and to respond to how these affect designers' process of drawing (Lee \& Yan, 2016).

\section{Lessons learned}

Based on the data obtained in this research, a number of comments pertaining to the main conclusions are presented below, along with some lessons that could be learned as a result. 
A) From the quantitative point of view, the most relevant facts are:

- The number of damages in flat roofs represents $68.66 \%$ of instances (approximately 3 out of every 4 cases);

- The most prevalent and impacting damages are: 'Localized infiltrations' - D04 (356 cases) and 'Infiltration humidity' - D01 (263 cases);

- Two of the above types of damages (out of seven possible), present in 619 cases, represent $77.27 \%$ of the total damage cases;

- There is a "29 to 77 " ratio, given that around $29 \%$ of the damages ( 2 out of 7 ) lead to around $77 \%$ of the anomalies; in other words, while it is not a classic Pareto ratio (20 to 80), it amounts to a similar proportion;

- Considering the basic pathological processes described in this study and relating them to the types of possible causes, it is found that the causes representing more than $10 \%$ of the total are: 'Absence/inadequate positioning of waterproofing membranes' - 08C (22.72\%) and 'Poor detailing of tail-ends in drains and grids' - 19C (12.61\%).

B) The third most prevalent cause is $21 \mathrm{C}$, which refers to inadequate or insufficient slopes. While this can be due to both design and execution issues, it is unlikely that roof plan slopes would be so different from that indicated in the project's technical documentation that one might consider it as being attributable solely to the execution stage. As for flat roofs in particular, there is a trend among some designers in Spain that prefer minimal slopes (down to 0\%). This leads to a number of problems: this is what is referred to as the " 5 th façade", visualizing roofs as large horizontal planes. With these results, the authors of this paper consider that the minimum legal slope of flat roofs should be $2 \%$, given that the current minimum of $1 \%$ (often converted to $0.5 \%$ in practice) leads often to cases of negative slope, due to poor execution or to exceeding tolerance limits.

C) The prevalence of deficiencies related to infiltration (despite the simplicity of the construction solutions) leads to questioning the intent of producing more complex roofs with a greater number of surfaces. Thus, green roofs (currently trendy) require greater specialization and maintenance than the rest. These roofs, instead of being solely ornamental, reinforce buildings' thermal and acoustic isolation, helping recycle $\mathrm{CO} 2$ and increasing the green spaces accessible to city residents. In the USA alone, the City Hall of Chicago, the California Academy of Sciences, the Empire State Building and the Jacob K Javits Convention Center in New York, to name a few (Benavente, 2015), have embraced green roofs. This is a reflection of the greater, and growing, awareness of the environment, as demonstrated by President Obama's plan to reduce CO2 emissions by at least 30\% (Davenport \& Davis, 2015). Equally, in France, with the law of August 17th 2015 of transition energy to clean sources, it is intended to install solar panels in roofs, along with a number of other important measures (Gouvernement de la France, 2015).

D) One of the most problematic points is the tail-end of the waterproofing with the perimeter parapets, since this is a location of pathological concentration. There are certain aspects of construction knowledge that should be taken into account for execution to be correctly carried out. Technical document DB-HS-1 of the Spanish regulation of this aspect (Ministerio de la Vivienda, 2006), indicates that the tail-end can be done via a clearance of $3 \times 3 \mathrm{~cm}$, with a reinforcement in the parapet's outer surface and by means of a metallic flange provided for the sealing. In function of the type of roof (self-protected, with gravel finishing, accessible, etc.), of the material the membrane is made of and of other variables, it is necessary for the intervening workers and technicians to be well aware of the steps to be followed to prevent mistakes in the construction. The second image in Figure 6 displays a three-dimensional model to adequately visualize this singularity (related to $24 \mathrm{C}$ and $26 \mathrm{C}$ anomalies).

E) Some research papers have noted that aspects as basic as the design of slopes, the thermal insulation and the ventilation systems or the specification of incompatible materials are the most frequent design errors (Garcez et al., 2015).

F) Other studies have noted the importance of roof maintenance processes, attributing importance to this theme. In this regard, in a study carried out in the USA on a selection of buildings, the costs of roof maintenance were quantified as about $17 \%$ of the total of Maintenance, Repair, and Rehabilitation (MR\&R) operations (Abate, Towers, Dotz, \& Romani, 2009).

G) An adequate process of verification and control of this element could easily reduce the occurrence of several anomalies. In this regard, some authors (Cruz Álvarez, 2010) stand for the maxim 'that which is supervised and controlled is converted into a guarantee of quality'.

This work has been developed within a Plan of Action approved in 2011 in the Musaat Foundation, in which an investigation in Spanish national territory on the anomalies of buildings was approved. 
The support of the CERIS-ICIST Research Institute, IST, Universidade de Lisboa and of FCT (Foundation for Science and Technology) is also acknowledged by the third author.

References

Abate, D., Towers, M., Dotz, R., \& Romani, L. (2009). The Whitestone Facility Maintenance and Repair Cost Reference 2009-2010 (14th Ed.). California, USA: Whitestone Research Corporation.

AENOR. (1996). UNE 104402: Roof Waterproofing Systems with Bituminous and Modified Bituminous Materials. Madrid, Spain: Asociación Española de Normalización y Certificación.

AENOR. (1999). UNE 104400-3:1999: Instructions for Placing on Site of Waterproofing Systems made of Asphaltic Membranes for Waterproofing and Rehabilitation of Roofs. Madrid, Spain: Asociación Española de Normalización y Certificación.

AENOR. (2009a). UNE 104416:2009: Roof Waterproofing Systems made of Synthetic Flexible Thin Membranes: Instructions, Control, use and Maintenance. Madrid, Spain: Asociación Española de Normalización y Certificación.

AENOR. (2009b). UNE 41805-9:2009: Diagnosis of Buildings. Part 9: Pathological Study of the Building. Roofs. Madrid, Spain: Asociación Española de Normalización y Certificación.

Azorín López, V., \& Monjo Carrió, J. (2005). La investigación en Construcción. Conclusiones de las I jornadas de investigación en Construcción. Informes de La Construcción, 5(498), 3-15.

Bails, B. (1796). De la Arquitectura Civil. Elementos de Matemática, -Tomo IX, Parte I-, Imprenta de la viuda de D. Joaquín Ibarra, Madrid.

Benavente, R. P. (2015). La expansión de los "green roofs": los diez jardines urbanos más espectaculares. Retrieved April 20, 2016, from http://www.elconfidencial.com/multimedia/album/tecnologia/2015-05-05/flores-en-el-tejado-los-quince-jardines-urbanos-masespectaculares-del-mundo_787647\#0

Carretero-Ayuso, M. J., \& de Brito, J. (2016). Analysis of the Execution Deficiencies of Flat Roofs with Bituminous Membranes. Journal of Performance of Constructed Facilities, 30(6), 4016049. https://doi.org/10.1061/(ASCE)CF.1943-5509.0000904

Carretero-Ayuso, M. J., \& de Brito, J. (2017). Multiparameter Evaluation of Deficiencies in Tiled Pitched Roofs. Journal of Performance of Constructed Facilities, 31(2), 4016097. https://doi.org/10.1061/(ASCE)CF.1943-5509.0000962

Carretero-Ayuso, M. J., \& Moreno-Cansado, A. (2013). Análisis Estadístico Nacional sobre Patologías en la Edificación: Años 2008 a 2010. Fundación Musaat. Madrid, Spain.

Chen, Y., Baskaran, A., \& Lei, W. (1998). Wind load resistance of modified bituminous roofing systems. Construction and Building Materials, 12(8), 471-480. https://doi.org/10.1016/S0950-0618(98)00025-7

Cruz Álvarez, J. J. (2010). Sistemas de Impermeabilización para Edificios. Revista de Arquitectura E Ingeniería, 4(3), 1-12.

Davenport, C., \& Hirschfeld Davis, J. (2015). Move to Fight Obama's Climate Plan Started Early. The New York Times. Retrieved from https://www.nytimes.com/2015/08/04/us/obama-unveils-plan-to-sharply-limit-greenhouse-gas-emissions.html?_r=0

Flores-Colen, I., de Brito, J., \& de Freitas, V. P. (2008). Stains in facades' rendering - Diagnosis and maintenance techniques' classification. Construction and Building Materials, 22(3), 211-221. https://doi.org/10.1016/j.conbuildmat.2006.08.023

Garcez, N., Lopes, N., Brito, J. de, \& Silvestre, J. (2012). System of inspection, diagnosis and repair of external claddings of pitched roofs. Construction and Building Materials, 35, 1034-1044. https://doi.org/10.1016/j.conbuildmat.2012.06.047

Garcez, N., Lopes, N., de Brito, J., \& Sá, G. (2012). Pathology, diagnosis and repair of pitched roofs with ceramic tiles: Statistical characterisation and lessons learned from inspections. Construction and Building Materials, 36, 807-819. https://doi.org/10.1016/j.conbuildmat.2012.06.049

Garcez, N., Lopes, N., de Brito, J., Sá, G., \& Silvestre, J. D. (2015). Influence of Design on the Service Life of Pitched Roofs' Cladding. Journal of Performance of Constructed Facilities, 29(3), 4014073-1-4014073-11. https://doi.org/10.1061/(ASCE)CF.1943-5509.0000461

Government of France. Law 2015-992 of August 17th 2015 on the Energy Transition for Green Growth (2015). France.

Guha, T. K., \& Kopp, G. A. (2014). Storm duration effects on roof-to-wall-connection failures of a residential, wood-frame, gable roof. Journal of Wind Engineering and Industrial Aerodynamics, 133, 101-109. https://doi.org/10.1016/j.jweia.2014.08.005

Guzmán, A. M., Martínez, D. I., \& González, R. (2014). Corrosion-erosion wear of refractory bricks in glass furnaces. Engineering Failure Analysis, 46, 188-195. https://doi.org/10.1016/j.engfailanal.2014.09.003

Harrison, H. W., Trotman, P. M., \& Saunders, G. K. (2010). Roofs and Roofing: Performance, Diagnosis, Maintenance, Repair and the Avoidance of Defects (BR 504) (Bre Building Elements Series) (3rd Editio). London, UK: Building Research Establishment.

Ko, K. P., Molleti, S., Bishop, M., Baskaran, A. (2006). "SIGDERS Wind Uplift Resistance Data on Mechanically Attached Single Ply Roofing Systems Effect of Steel Deck Parameters", National Research Council Canada, Institute for Research in Construction, Ottawa, Canada.

Kurtulus, A., \& Uygan, C. (2010). The effects of Google Sketchup based geometry activities and projects on spatial visualization ability of student mathematics teachers. Procedia - Social and Behavioral Sciences, 9, 384-389. https://doi.org/10.1016/j.sbspro.2010.12.169 
Lee, S., \& Yan, J. (2016). The impact of 3D CAD interfaces on user ideation: A comparative analysis using SketchUp and Silhouette Modeler. Design Studies, 44, 52-73. https://doi.org/10.1016/j.destud.2016.02.001

Mesa Fernández, J. M., Pacios González, C., Álvarez Cabal, V., \& Villanueva Balsera, J. (2016). Analysis of the quality control planning in residential construction projects in Spain. Revista de La Construcción, 15(2), 106-114. https://doi.org/10.4067/S0718-915X2016000200011

Ministerio de Vivienda. Real Decreto 314/200. (Agencia Estatal Boletín Oficial del Estado, Ed.), Código Técnico de la Edificación (2006). Spain. https://doi.org/10.1017/CBO9781107415324.004

MUSAAT. (2008-2010). “Expedientes e informes periciales de siniestros”, Mutua de Aparejadores y Arquitectos Técnicos, Madrid, Spain.

Napolano, L., Menna, C., Asprone, D., Prota, A., \& Manfredi, G. (2015). Life cycle environmental impact of different replacement options for a typical old flat roof. The International Journal of Life Cycle Assessment, 20(5), 694-708. https://doi.org/10.1007/s11367-015-0852-4

Paulo, P. V., Branco, F. A., \& Brito, J. de. (2011). Deterministic and Stochastic Prediction Models For the Buildings life Platform. In XII DBMC: 12th International Conference on Durability of Building Materials and Components. Porto, Portugal.

Piskoty, G., Wullschleger, L., Loser, R., Herwig, A., Tuchschmid, M., \& Terrasi, G. (2013). Failure analysis of a collapsed flat gymnasium roof. Engineering Failure Analysis, 35, 104-113. https://doi.org/10.1016/j.engfailanal.2012.12.006

Raposo, S., Fonseca, M., \& Brito, J. D. (2011). Planned Preventive Maintenance Activities: Analysis of Guidance Documents. In XII DBMC: 12th International Conference on Durability of Building Materials and Components. Porto, Portugal.

Sarman, S. M., Nawi, M. N. M., Che-Ani, A. I., \& Mazlan, E. M. (2015). Concrete flat roof defects in equatorial climates. International Journal of Applied Engineering Research, 10(3), 7319-7324.

SERJUTECA. (2008-2010). Expedientes y documentación de siniestros de responsabilidad civil profesional de aparejadores y arquitectos técnicos. Madrid, Spain.

Silva, R. R., Lopes, J. G., \& Correia, J. R. (2010). The effect of wind suction on flat roofs: An experimental and analytical study of mechanically fastened waterproofing systems. Construction and Building Materials, 24(1), 105-112. https://doi.org/10.1016/j.conbuildmat.2009.08.034

Solar Serrano, P. del. (2014). Sistemas de Gestión de la Calidad. Metodología para implementar proyectos de mejora continua para la reducción de los defectos de construcción en edificación de viviendas. Universidad Politecnica de Madrid.

Walter, A., de Brito, J., \& Grandão Lopes, J. (2005). Current flat roof bituminous membranes waterproofing systems - inspection, diagnosis and pathology classification. Construction and Building Materials, 19(3), 233-242. 